CARPATHIAN JOURNAL OF FOOD SCIENCE AND TECHNOLOGY

journal homepage: http://chimie-biologie.ubm.ro/carpathian_journal/index.html

\title{
EFFECT OF DRYING ON PHYSICAL AND FLOW PROPERTIES OF BANANA POWDER
}

\author{
Akshay Sonawane', Sumit Sudhir Pathak ${ }^{1}$, Rama Chandra Pradhan ${ }^{1 凶}$ \\ ${ }^{I}$ Department of Food Process Engineering, National Institute of Technology, Rourkela, India \\ هpradhanrc@nitrkl.ac.in \\ https://doi.org/10.34302/crpjfst/2021.13.3.14 \\ Article history: \\ Received: \\ 15 February 2020 \\ Accepted: \\ 1 July 2021 \\ Keywords: \\ Unripe banana powder; \\ Powder flow tester; \\ Flowability; \\ Hopper design.

\section{ABSTRACT} \\ Due to a lack of knowledge on the physical characteristics and flowability \\ of the powders, it makes it difficult to handle or design the process, \\ equipment, and handling machinery for powders. The research was inducted \\ to investigate the flow characteristics and flowability of the unripe (green) \\ banana powders, which were prepared by using two different drying \\ methods, viz. sun drying, and hot air drying. A comparative analysis of \\ physical characteristics and flow properties by using the Brookfield Powder \\ Flow Tester (PFT) was done between the hot air-dried and sun-dried powder \\ at an equal moisture content of $6.61 \%$ (wet basis), and these results showed \\ a trend that sun-dried powder has a better flow characteristic than the hot \\ air-dried unripe banana powder, which was found to more cohesive at equal \\ moisture contents. Hopper design showed that hot air-dried powder of unripe \\ banana requires higher hopper outlet dimension and hopper half angle than \\ sun-dried powder for mass flow through the conical-shaped hopper. The \\ knowledge of the physical and flow properties of unripe banana powder \\ would be useful in designing hoppers for the equipment in food industries.
}

\section{Introduction}

The banana (Musa acuminate) is a highly nutritious fruit that is produced and consumed all over the world. The ripen banana and unripe mature banana are rich in carbohydrate and fiber content. Besides these, it also contains phenolic acid, resistant starch, minerals, and vitamins. The unripe banana is readily available at a low cost hence can be processed into various products, which can be preserved for an extended period as ripening banana is very perishable. Thus unripe banana acts as a good potential for industrialization as a highly qualified food product and food diet (Yani, Arief, \& Mulyanti, 2013). The processing of unripe bananas involves the preparation of banana powder, peel powder, and fried chips (Singh, Kaushik, \& Gosewade, 2018).

The unripe banana powder (flour) is prepared using different drying methods such as hot air drying, sun drying, freeze-drying, and vacuum drying. On an industrial scale, sun drying and hot air drying techniques are used on a large scale. The different drying techniques used to form powder show different flow properties. The drying process removes water from food material, which may induce some changes in color, texture, density, porosity, sorption characteristics, and quality of dehydrated products (Mirhosseini \& Amid, 2013). The shelf life of green banana powder is longer than the fruit as it has lower water activity. The green banana powder is characterized by a good starch source, dietary fiber, resistant starch, and antioxidant compounds. Therefore, the green banana powder is widely used in the baking and confectionery industries for the preparation of cakes, puris, parathas, toffees, banana snacks, and crackers (Morin \& Briens, 2013). The 
unripe banana powder is available in the market. It can be used as an alternative for wheat or gluten in various food products such as weaning food, diet supplements, nutritional supplements, etc. It can be utilized in the preparation of vermicelli combination with a wheat powder. Increasing demands for green banana powder leads to a study of flow behavior properties of the powder for industrial purposes such as blending powders for new formulations, transfer of powders from silos, drums, hoppers, etc., feeding to packaging machines, compaction, and fluidization. The flowability, which indicates the ability of the powder to flow, is considered as one of the fundamental properties of the bulk solid. Flowability includes the Hausner ratio, Carr's index, compressibility, internal friction, wall friction, etc., properties altogether (Jenike, 1964; Kamath, Puri, \& Manbeck, 1994).

The food manufacturing and processing units face several problems while handling, storing, and packaging the powders. The standard flow function will help us to determine the flowability or flow behavior of powder products that are handled on an immense scale in the manufacturing or processing industries. These flow properties can be correlated to their various physical properties, viz. internal strength, gravity flow rate, and bulk density. The flowability is affected by physical properties which are used for designing equipment for handling (belt conveyor, screw conveyor, pneumatic conveyor, gravity conveyor, etc.), storing (bin, silo, hopper, bunkers, sacks, etc.), and processing (mixing, bagging, drying, milling, etc.) (Berry, Bradley, \& McGregor, 2015; Slettengren, Xanthakis, Ahrné, \& Windhab, 2016).

The paper covers a complete understanding of the powder flow behavior of green banana powder prepared by using two different drying methods, namely solar drying and hot air drying, with consideration of hopper design.

\section{Materials and methods}

\subsection{Preparation of unripe mature banana powder}

The mature green bananas of the Robusta variety were purchased from the local market of Rourkela, India. The bananas were washed by using potable water to clean them from dust and dirt. The bananas were peeled manually and were dipped into distilled water to avoid browning. The bananas were sliced into a thickness of $1 \mathrm{~cm}$ manually by using the slicer. The slices of bananas were treated for 10 minutes by using a $0.5 \%(\mathrm{~W} / \mathrm{V})$ citric acid solution (Singh, Suvartan, \& Sukriti, 2017). After treatment, the slices were drained from the solution and were distributed into two equal lots for drying.

Table 1. Nomenclature

\begin{tabular}{|c|c|}
\hline \multicolumn{2}{|r|}{ Nomenclature } \\
\hline SEM & Scanning Electron Microscope \\
\hline $\mathrm{d}_{50}$ & $\begin{array}{l}\text { Particle size below which } 50 \% \text { of } \\
\text { material volume exists - median, } \mu \mathrm{m}\end{array}$ \\
\hline $\mathrm{CI}$ & Compressibility Index, \% \\
\hline HR & Hausner Ratio \\
\hline FF & Flow function curve \\
\hline$\sigma_{1}$ & $\begin{array}{l}\text { Major Principle Consolidation Stress } \\
\text { (MPC), KPa }\end{array}$ \\
\hline$\sigma_{\mathrm{c}}$ & $\begin{array}{l}\text { Unconfined Failure Strength (UFS), } \\
\text { Kpa }\end{array}$ \\
\hline$\varepsilon$ & Consolidation stress, Kpa \\
\hline $\mathrm{C}$ & Cohesion, Kpa \\
\hline$\delta_{\mathrm{c}}$ & Critical angle of internal friction, ${ }^{\circ}$ \\
\hline$\delta_{\mathrm{e}}$ & Effective angle of internal friction, ${ }^{\circ}$ \\
\hline$\phi_{\mathrm{w}}$ & Effective angle of wall friction, ${ }^{\circ}$ \\
\hline$\rho_{\mathrm{lb}}$ & Loose poured bulk density, $\mathrm{Kg} / \mathrm{m}^{3}$ \\
\hline$\rho_{\mathrm{p}}$ & Particle density, $\mathrm{Kg} / \mathrm{m}^{3}$ \\
\hline$\rho_{\mathrm{c}}$ & Critical bulk density, $\mathrm{Kg} / \mathrm{m}^{3}$ \\
\hline$\rho_{\mathrm{t}}$ & Tapped bulk density, $\mathrm{Kg} / \mathrm{m}^{3}$ \\
\hline $\mathrm{D}$ & Hopper outlet dimension, $\mathrm{m}$ \\
\hline$\theta$ & Hopper half-angle,$~^{\circ}$ \\
\hline $\begin{array}{l}\mathrm{L}^{*}, \mathrm{a}^{*} \text {, and } \\
\mathrm{b}^{*}\end{array}$ & Color values \\
\hline $\mathrm{R}^{2}$ & Coefficient of determination \\
\hline
\end{tabular}

The first lot was sundried for 12 hours at the atmospheric condition. The relative humidity varied from 31 to $35 \%$, and temperature approximately changed from 32 to $40^{\circ} \mathrm{C}$ in May. The second lot was subjected to hot air drying at $50^{\circ} \mathrm{C}$ for 24 hours in Hot Air Oven Tray Dryer 
(Khera Instruments Pvt. Ltd., India). The hot air was circulated at a speed of $0.4 \mathrm{~m} / \mathrm{sec}$ over unripe banana slices (Sonawane et al., 2021).

After the completion of drying, each lot was brought to room temperature. Each lot was ground for 2 minutes at the speed of $12000 \mathrm{rpm}$ by using the mixer grinder (Philips, India). After grinding, the powder was sieved by using the ISS 20 sieve to get a uniform size fine powder. Both the powders were kept in a desiccator at $27 \pm 2^{\circ} \mathrm{C}$ for 24 hours to equalize the moisture content of powders by moisture migration. The moisture content of unripe banana powder was measured as per the standard method (AOAC, 2002). Then fine powder was packaged into high-density polyethylene (HDPE) bags, stored at $25 \pm 2^{\circ} \mathrm{C}$ temperature for further experiments (Bezerra, Rodrigues, Amante, \& Silva, 2013). Thus each powder is ready for measuring its flow properties.

\subsection{Physical properties of unripe banana powder}

Malvern Mastersizer $3000 \quad$ (Malvern Instruments, United Kingdom) was used for the particle size determination size of powder particles. The particle size analyzer gives the value of d50, which represents the average particle size of the powder. Scanning Electron Microscope (SEM) (Oxford Instruments, United Kingdom) was also used to analyze particles' shape.

The mass of powder divided by the total volume of powder is called the bulk density of the powder $\left(\rho_{b}\right)$. To measure loose poured bulk density $\left(\rho_{\mathrm{lb}}\right)$, the powder is allowed to settle freely by gravity without any load (Jaggi, Leaper, \& Ingham, 2016). Both bulk density and loose poured density were measured manually by simply pouring the known powder mass in a cylinder and then cross-checked by the readings obtained in the standard flow function test. The following formulae were used for the determination of porosity, Hausner ratio, and Carr's index (Ji, Fitzpatrick, Cronin, Fenelon, \& Miao, 2017; Li, Roos, \& Miao, 2016a, 2016b):

Porosity $=1-\left(\rho_{\mathrm{lb}} / \rho_{\mathrm{p}}\right)$
Compressibility Ratio $=\left(\rho_{t} / \rho_{\mathrm{lb}}\right)$

Carr's Index $=100\left(1-\rho_{\mathrm{lb}} / \rho_{\mathrm{t}}\right)$

The particle density of powder was measured by powder density meter (Smart Instruments Company Pvt. Ltd., India), which works on the principle of pycnometer by introducing the helium gas in the sample.

The color values of two powder samples were measured directly using the colorimeter (Hunter Lab Colorimeter, USA). The values of $\mathrm{L}^{*}, \mathrm{a}^{*}$, and $\mathrm{b}^{*}$ were calculated for each sample by changing the position of the sample through an angle over the instrument (Pathak, Pradhan, \& Mishra, 2019; Sonawane, Pathak, \& Pradhan, 2020a; Sonawane, Pathak, \& Pradhan, 2020b).

\subsection{Standard flow function and wall friction test}

To measure the standard flow function and wall friction test of the banana powder, the Powder Flow Tester (PFT) (Brookfield, United Kingdom) was used with torsional and axial speeds of $1.0 \mathrm{rev} \mathrm{h}-1$ and $1.0 \mathrm{~mm} \mathrm{~s}-1$, respectively. PFT works on Jenike's methodology, which involves the application of consolidation stress with given axial and torsional speed through the annular lid to the powder present in the shear cell of annular shape to induce shear in the powder at given consolidation stress (Garg, Mallick, GarciaTrinanes, \& Berry, 2018). The banana powder was loaded into the sample holder, and the test was run using the powder flow software. The flow properties were determined by using a standard vane lid. The measured results and graphs were recorded separately for each of the powders, which were dried by using different methods. The standard flow test consists of 35 runs of consolidation stresses for each sample and takes around 35 minutes to complete the test. It gives the values of normal stresses, bulk density of powder corresponding to an angle of internal friction, unconfined failure strength (UFS), major principal consolidation stress (MPC), critical arching values for hopper design, flow function curve (FF), and cohesion (C). It is used for equipment design and quality 
control (Fitzpatrick, Barry, Delaney, \& Keogh, 2005).

The standard vane lid was replaced by the wall friction lid for standard wall friction test. The test was carried out by using a new sample of powder for a test of wall friction. The measured results and graphs were recorded separately for both the powder samples, which were dried using different methods. This test takes around 15 minutes and gives values for the effective angle of wall friction $\left(\phi_{\mathrm{w}}\right)$, Hausner Ratio (HR) (compressibility ratio), Carr's Index (compressibility index) (CI), and hopper halfangle $(\theta)$ (Crowley, Gazi, Kelly, Huppertz, \& O'Mahony, 2014).

\subsection{Hopper design}

There are two gravity powder flow patterns, namely core flow and mass flow, in the processing industry (Figure 1). Rat-holing and arching are the primary obstructions in designing the hopper for core and mass flow, respectively. For poor flowing powders, the conical hopper with mass flow patterns is generally used on a large scale. To achieve easy discharge of powder, the wall of the conical hopper must be adequately smooth and steep (AMETEK Brookfield Engineering, 2019).

\subsection{Statistical analysis}

All physical properties of hot air and sundried unripe banana powder were determined in triplicates and converted to average values with their standard deviations. The analysis of variance (ANOVA) was performed by using SPSS 20.0 software with Duncan test at the significance level of $5 \%$ and presented in the tables.

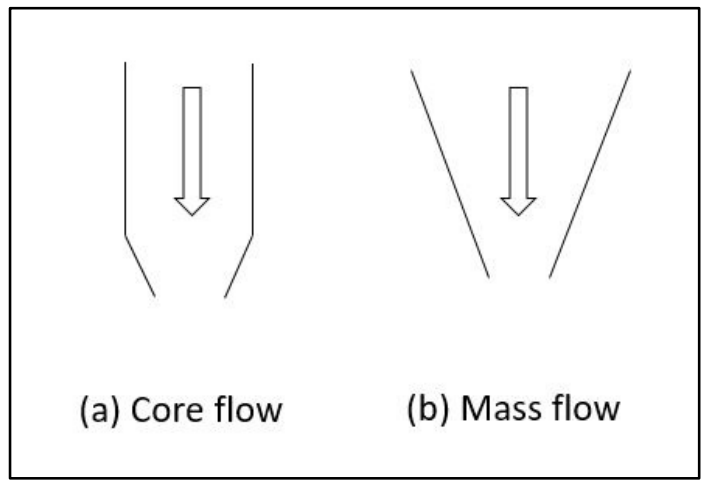

Figure 1. Core and mass flow of powders

\section{Results and discussions}

\subsection{Physical properties of powders}

The moisture contents of the hot air and sundried unripe banana powder were $6.61 \%$ (wet basis). As per the results of the SEM, the geometry of the hot air-dried powder particles was found to be more spheroid and ellipsoid than sun-dried powders (Figure 2). The structural changes in the matrix of slices occurred during its drying processes, and a larger size of particles was formed in sun-dried unripe banana powder during the grinding of slices. The hot, air-dried, unripe banana powder has given a high value of $\mathrm{L}^{*}$ (lightness). While it showed lower values of $\mathrm{a}^{*}$ (red to green) and $\mathrm{b}^{*}$ (yellow to blue) than sun-dried powder. The comparison between color values is shown in Figure 3 . The values of $d_{50}$ for hot air and sundried powders were $11.5 \mu \mathrm{m}$ and $17.9 \mu \mathrm{m}$, respectively, and it indicates the average particle size of powder (Table 2).

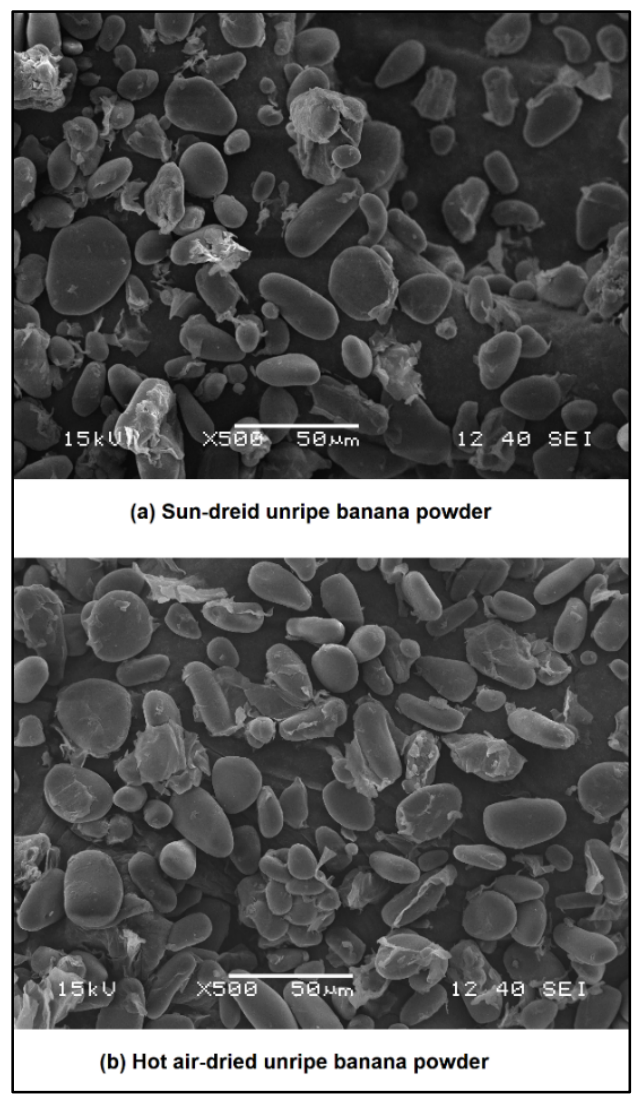

Figure 2. SEM analysis of sun-dried and hot air-dried unripe banana powders 
The powder with lower bulk density has higher structural strength and internal friction between particles, which opposes the collapsing of powder when it is poured into a container. On the other hand, the powder with high bulk density has weaker structural strength, allowing collapsing (Abdullah \& Geldart, 1999). The particle densities of hot air dried and sun-dried unripe banana powders were $600.2 \mathrm{~kg} / \mathrm{m} 3$ and $559.5 \mathrm{~kg} / \mathrm{m} 3$ with a porosity of 0.426 and 0.552 , respectively, as shown in Table 2 . The bulk density as well as tapped density of hot air-dried powder was higher than sun-dried powder. Thus the hot air-dried unripe banana powder has shown higher structural strength and internal friction.

The average particle size of the hot air-dried powder is lower than the sun-dried powder (Table 2). The cohesiveness of hot air-dried powder has been increased by the van der Waal forces of attraction due to the presence of fine particles in it (Jackson, Sinka, \& Cocks, 2007). This causes more resistance to the flow of particles for hot air-dried powder. The Hausner ratio (HR) and compressibility index (CI) of hot air-dried powder were higher as compared to sun-dried powder (Table 2). Table 3 shows the flowability of powders concerning the Hausner ratio and compressibility index values. From Table 3, the hot air and sun-dried powders have shown very poor flowability and poor flowability, respectively.
During the hot air drying process, the glycosidic bonds of starch (polymeric carbohydrates) were broken in large amounts as it is a continuous forced drying technique. In addition to that, there was more retrogradation effect (syneresis) in the starch structure due to the release of water in the hot air drying process. On the other hand, there may be more amount of amylose present in sun-dried unripe banana powder may increase the hardness of starch due to less retrogradation effect and consequently larger particle size of sun-dried unripe banana powder. These reasons have shown less flowability of hot air-dried unripe banana powder than sun-dried unripe banana powder (Mirhosseini \& Amid, 2013).

Table 2. Physical properties of the hot air and sun-dried unripe banana powder.

\begin{tabular}{|l|l|l|}
\hline Powder & Hot air dried & Sun-dried \\
\hline $\mathbf{d}_{\mathbf{5 0}}(\boldsymbol{\mu m})$ & $11.5 \pm 1.05$ & $17.9 \pm 1.17$ \\
\hline $\boldsymbol{\rho}_{\mathbf{l b}}\left(\mathbf{k g} / \mathbf{m}^{\mathbf{3}}\right)$ & $600.24 \pm 15.75$ & $559.59 \pm 13.44$ \\
\hline $\boldsymbol{\rho}_{\mathbf{p}}\left(\mathbf{k g} / \mathbf{m}^{\mathbf{3}}\right)$ & $1248.90 \pm 26.17$ & $1024.63 \pm 24.31$ \\
\hline $\boldsymbol{\rho}_{\mathbf{t}}\left(\mathbf{k g} / \mathbf{m}^{\mathbf{3}}\right)$ & $903.27 \pm 22.29$ & $776.73 \pm 20.44$ \\
\hline Porosity & $0.53 \pm 0.02$ & $0.45 \pm 0.02$ \\
\hline HR & $1.51 \pm 0.11$ & $1.36 \pm 0.09$ \\
\hline CI $(\%)$ & $0.33 \pm 0.01$ & $0.27 \pm 0.01$ \\
\hline $\begin{array}{l}\text { Color } \\
\text { values } \\
\mathbf{L}\end{array}$ & $81.82 \pm 2.44$ & $86.40 \pm 3.28$ \\
$\mathbf{a}$ & $2.18 \pm 0.08$ & $2.16 \pm 0.07$ \\
$\mathbf{b}$ & $11.58 \pm 0.55$ & $10.74 \pm 0.51$ \\
\hline
\end{tabular}

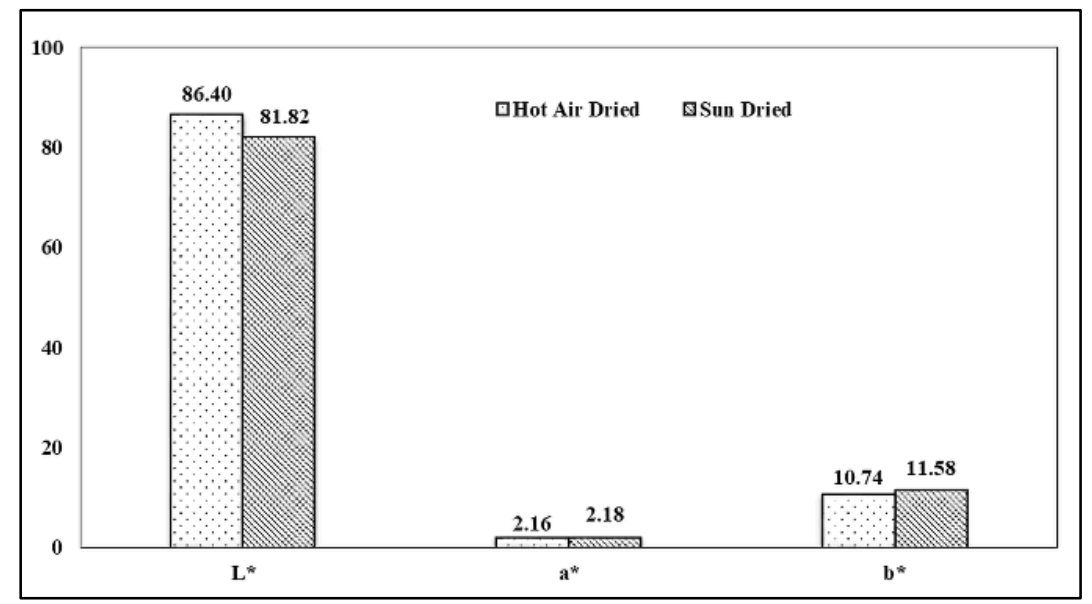

Figure 3. Color values of hot air and sun-dried unripe banana powder. 
Table 3. Specification of Carr's Index and Hausner Ratio for flowability.

\begin{tabular}{|l|l|l|}
\hline Flow character & $\begin{array}{l}\text { Carr's } \\
\text { index (\%) }\end{array}$ & $\begin{array}{l}\text { Hausner } \\
\text { ratio }\end{array}$ \\
\hline Excellent & $\leq 10$ & $1.00-1.11$ \\
\hline Good & $11-15$ & $1.12-1.18$ \\
\hline Fair & $16-20$ & $1.19-1.25$ \\
\hline Possible / Passable & $21-25$ & $1.26-1.34$ \\
\hline Poor & $26-31$ & $1.35-1.45$ \\
\hline Very poor & $32-37$ & $1.46-1.59$ \\
\hline Very, very poor & $>38$ & $>1.60$ \\
\hline
\end{tabular}

Source: Singh \& Kumar (2012).

\subsection{Yield locus and flow function curve}

The five yield loci have given the values of pre-shear stress, unconfined failure strength (UFS), and major principle consolidation stress (MPC). The shear stress value of yield locus was determined by Mohr-Coulomb failure criteria (Jager, Bramante, \& Luner, 2015; Crowley et al., 2014). The pre-shear stress values for hot airdried powder were $0.31,0.61,1.21,2.41$, and 4.85 KPa, whereas the pre-shear stresses values for sun-dried powder were $0.31,0.61$, $1.20,2.41$, and $4.85 \mathrm{KPa}$, as shown in Table 4. The Mohr-Coulomb failure criteria were produced by Brookfield PFT in standard flow test when an instrument was operating in operational stress range.

The plot between major principle consolidation stress $\left(\sigma_{1}\right)$ and unconfined failure strength $\left(\sigma_{c}\right)$ is called as flow function curve. It is divided into four regions, namely non-flowing, easy flowing, free-flowing, cohesive, and very cohesive according to Jenike's flowability classification as shown in Figure 2 for the hot air and sun-dried powder (Mistry, 2002). The flowability of powder is given by the flow function curve, and it depends on applied stress (Crowley et al., 2014). The flowability behavior for the hot air and sun-dried powder has been given by the flow function curve from very cohesive to cohesive and cohesive to easy flowing, but sun-dried powder has shown better flowability than hot air-dried unripe banana powder for corresponding major principle consolidation stress (Figure 4). The flow function curve is helpful in hopper design at different fill heights.

\subsection{Effective angle of internal friction, angle of wall friction, and bulk density}

The variation of bulk density $(\rho b)$ for the hot air and sun-dried powder has been shown in Figure 5 concerning major principle consolidation stress. The hot air, as well as sun-dried powder, showed an increase in bulk density as major principle consolidation stress (MPC) increases. The bulk density of the hot air-dried powder was higher than the sun-dried powder for all values of MPC. Thus the hot air-dried powder showed more compactness due to fine particles and more cohesion between particles.

The effective angle of internal friction $\left(\delta_{e}\right)$ represents the friction in between the layers of the powder, and it is given by major principle consolidation stress divided by minor principle consolidation stress during steady-state flow. Figure 6 shows the effect of major principle consolidation stress on the effective angle of internal friction. Both cohesive forces, as well as frictional force, contributes to the effective angle of internal friction. For hot air and sun-dried unripe banana powder, the effective internal friction angle was more significant at lower major principle consolidation stress. It decreased with an increase in the consolidation stress.

The hot air-dried powder has given a higher effective angle of internal friction than sun-dried powder. Due to smaller particle size, there would be more particle-particle interaction, and interlocking which leads to more van der Waal effect, which represents cohesive force developed between particles, and this increases the effective angle internal friction for hot air-dried unripe banana powder (Crowley et al., 2014; Mistry, 2002) 
Table 4. Flow property test data for the hot air and sun-dried unripe banana powder.

\begin{tabular}{|c|c|c|c|c|}
\hline $\begin{array}{c}\text { Consolidation } \\
\text { endpoint } \\
\text { (Yield locus) }\end{array}$ & $\begin{array}{c}\text { Major } \\
\text { principal } \\
\text { consolidating } \\
\text { stress }\end{array}$ & $\begin{array}{c}\text { Unconfined } \\
\text { failure } \\
\text { strength }\end{array}$ & Cohesion & $\begin{array}{c}\text { Effective } \\
\text { angle of } \\
\text { internal } \\
\text { friction }\end{array}$ \\
\hline (KPa) & (KPa) & (KPa) & (KPa) & $\mathbf{(}^{\mathbf{o}}$ \\
\hline \multicolumn{5}{|c|}{ Hot air-dried powder } \\
\hline 0.31 & $0.52 \pm 0.02^{\mathrm{a}}$ & $0.36 \pm 0.01^{\mathrm{a}}$ & $0.11 \pm 0.01^{\mathrm{a}}$ & $49.90 \pm 2.57^{\mathrm{a}}$ \\
\hline 0.61 & $1.01 \pm 0.07^{\mathrm{b}}$ & $0.54 \pm 0.02^{\mathrm{b}}$ & $0.16 \pm 0.01^{\mathrm{b}}$ & $41.10 \pm 1.81^{\mathrm{b}}$ \\
\hline s1.21 & $1.99 \pm 0.12^{\mathrm{c}}$ & $0.79 \pm 0.04^{\mathrm{c}}$ & $0.23 \pm 0.01^{\mathrm{c}}$ & $37.30 \pm 1.37^{\mathrm{c}}$ \\
\hline 2.41 & $3.94 \pm 0.19^{\mathrm{d}}$ & $1.11 \pm 0.05^{\mathrm{d}}$ & $0.34 \pm 0.01^{\mathrm{d}}$ & $34.50 \pm 1.21^{\mathrm{d}}$ \\
\hline 4.85 & $7.80 \pm 0.25^{\mathrm{e}}$ & $1.63 \pm 0.07^{\mathrm{e}}$ & $0.53 \pm 0.02^{\mathrm{e}}$ & $32.70 \pm 1.14^{\mathrm{e}}$ \\
\hline \multicolumn{5}{|c|}{ Sun-dried powder } \\
\hline 0.31 & $0.55 \pm 0.01^{\mathrm{a}}$ & $0.37 \pm 0.01^{\mathrm{a}}$ & $0.11 \pm 0.01^{\mathrm{a}}$ & $45.40 \pm 2.11^{\mathrm{a}}$ \\
\hline 0.61 & $1.07 \pm 0.04^{\mathrm{b}}$ & $0.52 \pm 0.02^{\mathrm{b}}$ & $0.15 \pm 0.01^{\mathrm{b}}$ & $38.90 \pm 2.02^{\mathrm{b}}$ \\
\hline 1.20 & $2.11 \pm 0.09^{\mathrm{c}}$ & $0.77 \pm 0.02^{\mathrm{c}}$ & $0.22 \pm 0.01^{\mathrm{c}}$ & $35.00 \pm 2 . .14^{\mathrm{c}}$ \\
\hline 2.41 & $4.15 \pm 0.15^{\mathrm{d}}$ & $1.08 \pm 0.05^{\mathrm{d}}$ & $0.33 \pm 0.02^{\mathrm{d}}$ & $32.04 \pm 2.28^{\mathrm{d}}$ \\
\hline 4.85 & $8.20 \pm 0.29^{\mathrm{e}}$ & $1.66 \pm 0.05^{\mathrm{e}}$ & $0.51 \pm 0.02^{\mathrm{e}}$ & $31.10 \pm 1.51^{\mathrm{d}}$ \\
\hline
\end{tabular}

${ }^{a-e}$ Means within the column with different superscripts are significantly different $(\mathrm{p}<0.05)$.

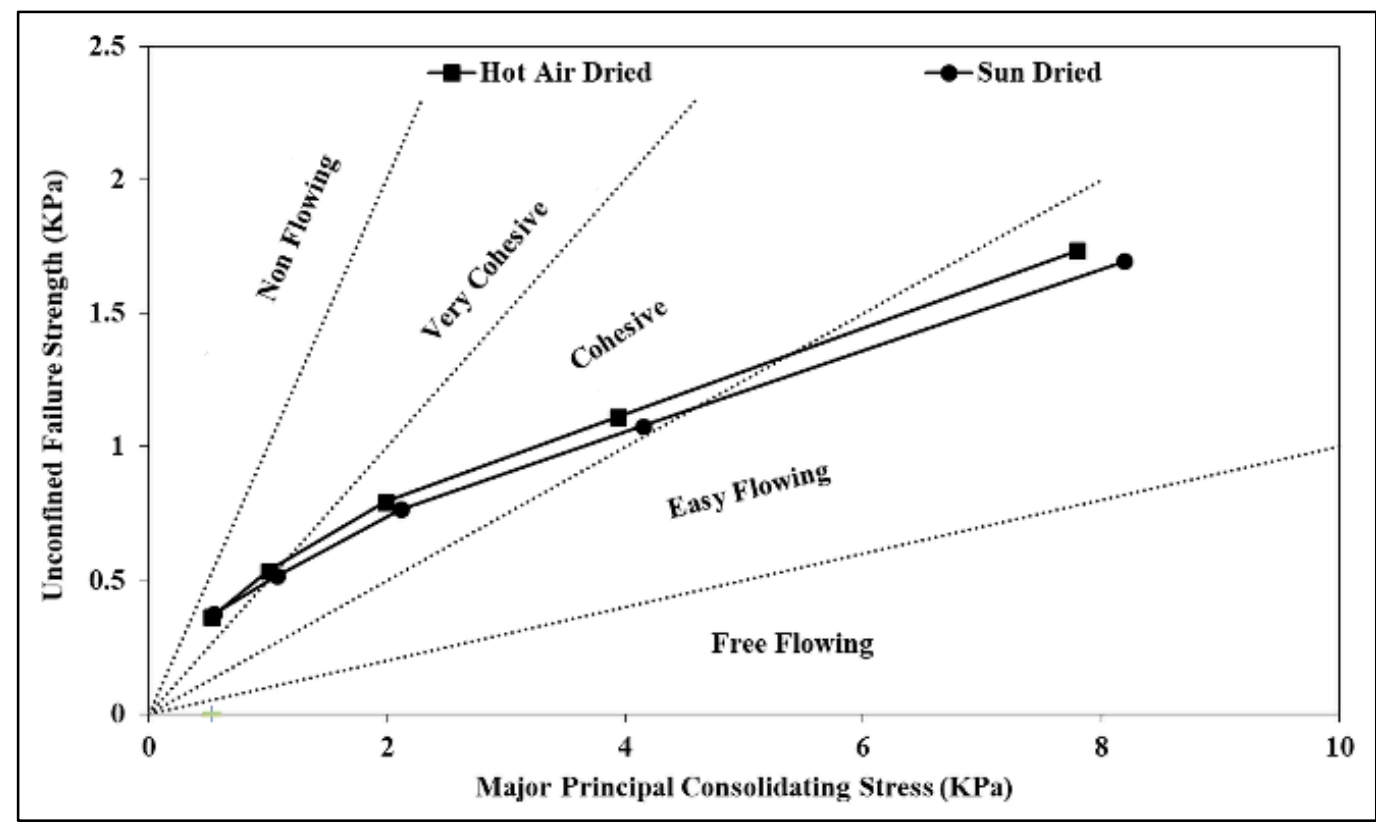

Figure 4. Flow function curve of the hot air and sun-dried unripe banana powder. 


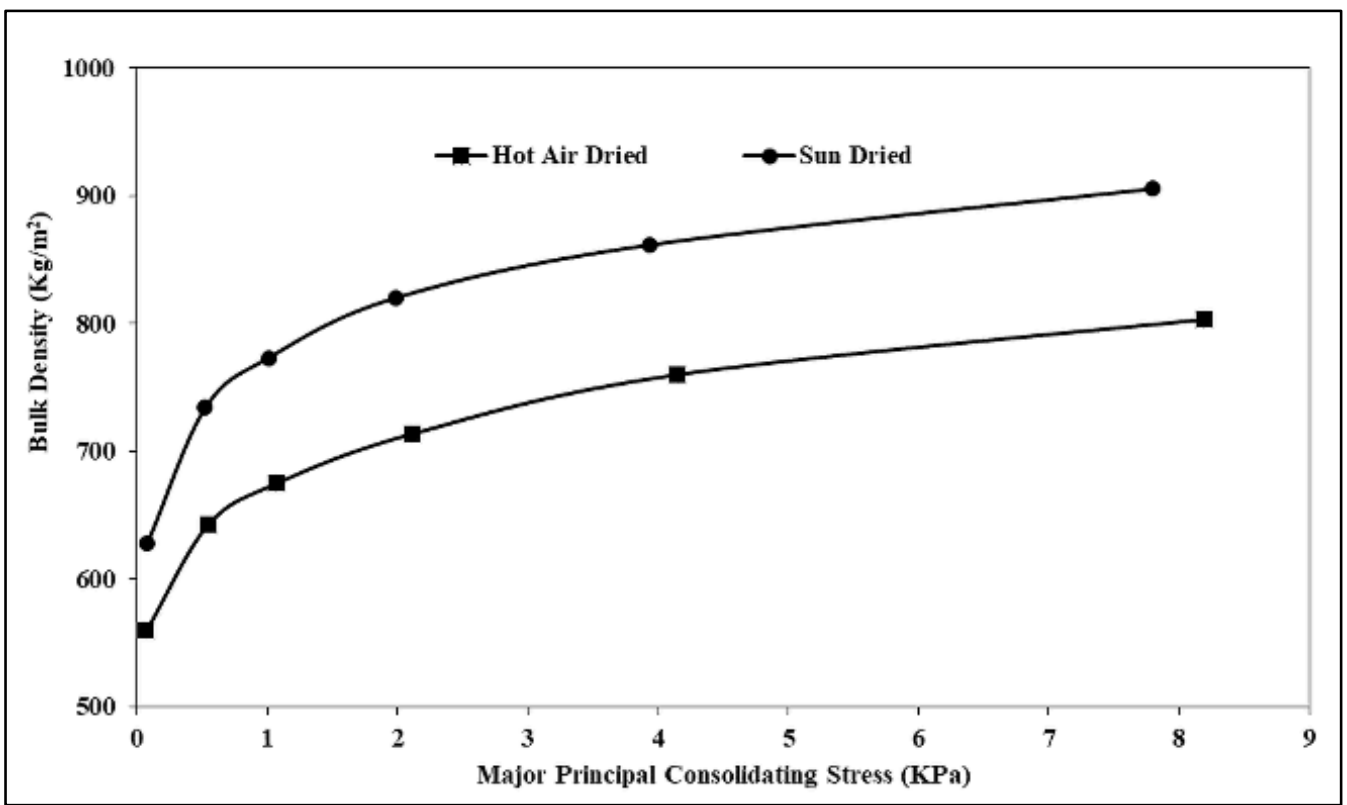

Figure 5. Bulk density as a function of major principle consolidation stress (MPC) for the hot air and sun-dried unripe banana powder.

The wall friction angle $\left(\phi_{\mathrm{w}}\right)$ represents friction between the powder particles and the wall surface at normal stresses, and it is given by the equation (4).

$\phi_{\mathrm{w}}=\arctan (\mu)$

Where $\mu$ is the coefficient of wall friction, determined by the slope of a straight line at the normal stress passing across the origin to the maximum yield locus, Figure 7 shows that an increase in normal stress also causes an increment in the wall friction angle. Still, the rate of increase in wall friction angle decreases gradually as normal stress increases. The hot air-dried unripe banana powder has shown a higher wall friction angle than sun-dried. The reasons behind the high wall friction angle for hot air-dried powder are smaller particle size and more adhesion between wall and particle of powder.

\subsection{Design of hopper for mass flow}

The design of a conical shape hopper includes a hopper outlet dimension (D) and hopper half-angle $(\theta)$ for mass flow. The Hopper dimension is the outer diameter of the conical hopper through which the flow of solid particles occurs, and the hopper halfangle is an angle made by the hopper wall to the vertical axis. The critical arching represents the design parameters at which powder can't collapse under its self-weight. For the steady flow state of powder, the design parameters of the hopper should be greater than critical arching values at corresponding stresses. Jenike, A.W. (1964) has done foundation work for deriving the equation for conical hopper. The standard flow function gives the data required for hopper design. The equations for hopper dimension (critical outlet diameter) and hopper half angle are given by equations (5) and (6), respectively (Garg et al., 2018).

$$
\begin{aligned}
& \mathrm{D}=\left(2 \times 1000 \times \sigma_{\mathrm{c}}\right) /\left(\mathrm{g} \times \rho_{\mathrm{c}}\right) \\
& \theta=\left[90-0.5 \arccos \left(\left(1-\sin \delta_{\mathrm{c}}\right) /\left(2 \sin \delta_{\mathrm{c}}\right)\right)\right]- \\
& 0.5\left[\phi_{\mathrm{w}}+\arcsin \left(\sin \phi_{\mathrm{w}} / \sin \delta_{\mathrm{c}}\right)\right]
\end{aligned}
$$




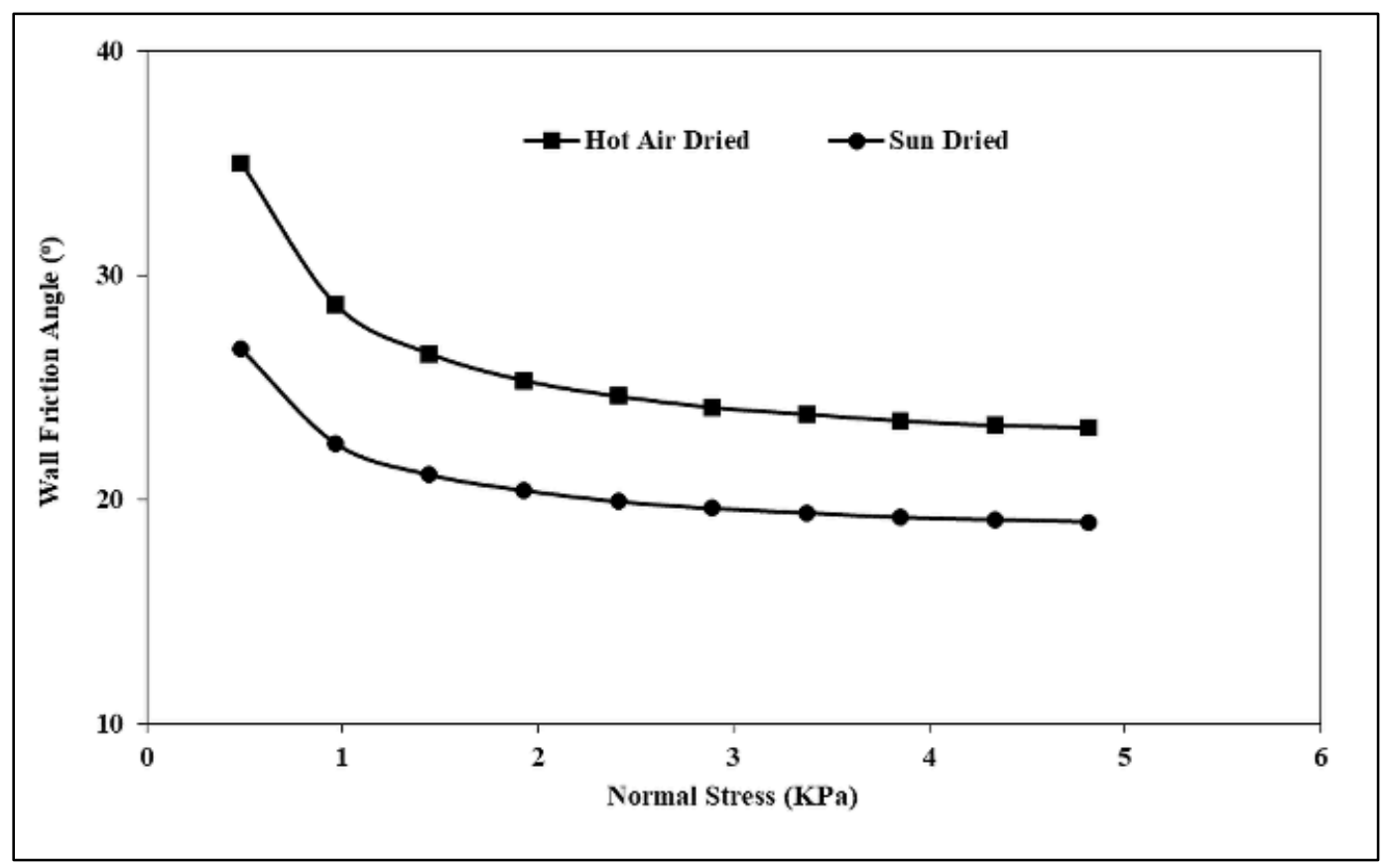

Figure 7. Effective angle of wall friction against normal stress for the hot air and sun-dried unripe banana powder.

Where $\mathrm{g}$ is the acceleration due to gravity $(\mathrm{m} / \mathrm{s} 2), \sigma_{\mathrm{c}}$ is critical consolidation stress, and $\rho_{\mathrm{c}}$ is critical bulk density corresponding to critical consolidation stress. The wall friction angle plays a dominant role in the calculation of the hopper half-angle.

The values of $\sigma_{c}$ and $\rho_{c}$ were taken from the data of bulk density and flow function (FF) graph. The value of $\phi_{\mathrm{w}}$ was taken from the data wall friction test (Figure 4) at a corresponding value of critical consolidation stress in the standard flow test. The critical arching value of hopper outlet diameter for hot air-dried was $0.116 \mathrm{~m}$ at $0.362 \mathrm{KPa}$; similarly, for sun-dried, it was $0.086 \mathrm{~m}$ at $0.300 \mathrm{KPa}$. Figure 8 shows the graph of hopper outlet versus hopper half-angle. The outlet dimension and hopper half-angle for hot air-dried powder were higher than sundried unripe banana powder at corresponding consolidation. This is because of smaller particle size and higher cohesion between particles of hot air-dried unripe banana powder (Table 4).

The linear relation between hopper half-angle and outlet dimension for hot air and sun-dried unripe banana powder is shown in equations (8) and (9).

$$
\begin{aligned}
& \theta=36.97 \mathrm{D}+15.53 \\
& \theta=58.59 \mathrm{D}+2.62
\end{aligned}
$$

Both regression equations have given $\mathrm{R}^{2}$ values of 0.97 , which is acceptable for designing dimensions of the hopper. 


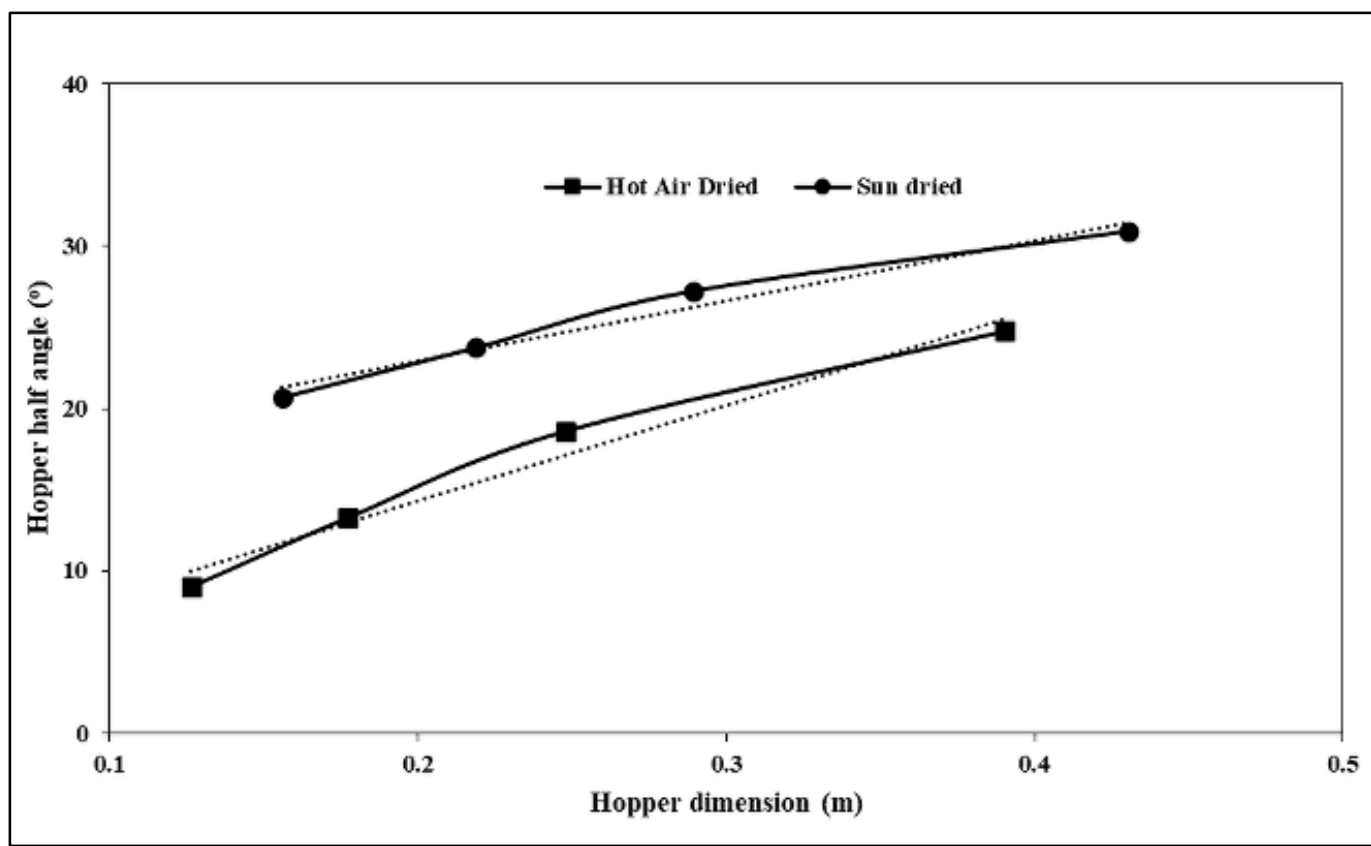

Figure 8. Hopper outlet dimension versus hopper half-angle for the hot air and sun-dried unripe banana powder.

\section{Conclusions}

The physical characteristics and flowability of unripe banana powders prepared by hot air tray drying and sun drying method were studied at an equal moisture content of $6.61 \%$ (wet basis). By comparing the physical characteristics, it was concluded that the hot air-dried powder had a smaller particle size and higher bulk density than sundried powder; conversely, the sun-dried powder had a smaller tapped density, porosity, and particle density than hot airdried powder. From the values of Hausner ratio, compressibility index, and flow function curve, the hot air-dried unripe banana powder was found to be more cohesive and less flowable than sun-dried powder due to structural changes in starch during the drying process. The hot air-dried unripe banana powder required a higher hopper outlet dimension and hopper half angle due to its low flowability than sundried powder to achieve desirable mass flow. The drying method for unripe banana powder has shown a more significant effect on the flowability of powders. The results obtained from the inducted research will form an essential database for the manufacturers, processors, processes, and equipment designers for the various unit operations such as handling, storing, and packaging of unripe banana powder.

\section{References}

Abdullah, E. C., \& Geldart, D. (1999). The use of bulk density measurements as flowability indicators. Powder technology, 102(2), 151-165.

AMETEK Brookfield Engineering: https://www.brookfieldengineering.com/ learning-center/learn-about-powderflow-analysis/what-is-powder-flowanalysis (last checked on Feb. 1st, 2020). AOAC. (2002). Association of official methods of analysis (17th ed.) (Method No. 630.24 A88 2002) Gaithersburg, Maryland, USA.

Berry, R., Bradley, M., \& McGregor, R. (2015). Brookfield powder flow testerResults of round robin tests with CRM116 limestone powder. Proceedings of the Institution of Mechanical Engineers, 
Part E: Journal of Process Mechanical Engineering, 229(3), 215-230.

Bezerra, C. V., Rodrigues, A. M. d. C., Amante, E. R., \& Silva, L. H. M. d. (2013). Nutritional potential of green banana flour obtained by drying in spouted bed. Revista Brasileira de Fruticultura, 35(4), 1140-1146.

Crowley, S. V., Gazi, I., Kelly, A. L., Huppertz, T., \& O'Mahony, J. A. (2014). Influence of protein concentration on the physical characteristics and flow properties of milk protein concentrate powders. Journal of Food Engineering, 135, 31-38.

Fitzpatrick, J., Barry, K., Delaney, C., \& Keogh, K. (2005). Assessment of the flowability of spray-dried milk powders for chocolate manufacture. Le Lait, 85(45), 269-277.

Garg, V., Mallick, S., Garcia-Trinanes, P., \& Berry, R. J. (2018). An investigation into the flowability of fine powders used in pharmaceutical industries. Powder Technology, 336, 375-382.

Jackson, S., Sinka, I., \& Cocks, A. (2007). The effect of suction during die fill on a rotary tablet press. European Journal of Pharmaceutics and Biopharmaceutics, 65(2), 253-256.

Jager, P. D., Bramante, T., \& Luner, P. E. (2015). Assessment of pharmaceutical powder flowability using shear cell-based methods and application of Jenike's methodology. Journal of Pharmaceutical Sciences, 104(11), 3804-3813.

Jaggi, V., Leaper, M. C., \& Ingham, A. (2016). Measuring the flow properties of small powder samples using an avalanche tester. Drying Technology, 34(6), 723728.

Jenike, A. W. (1964). Storage and flow of solids. Bulletin No. 123, Utah State University.

Ji, J., Fitzpatrick, J., Cronin, K., Fenelon, M. A., \& Miao, S. (2017). The effects of fluidised bed and high shear mixer granulation processes on water adsorption and flow properties of milk protein isolate powder. Journal of Food Engineering, 192, 19-27.

Kamath, S., Puri, V., \& Manbeck, H. (1994). Flow property measurement using the Jenike cell for wheat flour at various moisture contents and consolidation times. Powder Technology, 81(3), 293297.

Li, R., Roos, Y. H., \& Miao, S. (2016a). The effect of water plasticization and lactose content on flow properties of dairy model solids. Journal of Food Engineering, 170, 50-57.

Li, R., Roos, Y. H., \& Miao, S. (2016b). Influence of pre-crystallisation and water plasticization on flow properties of lactose/WPI solids systems. Powder Technology, 294, 365-372.

Mirhosseini, H., \& Amid, B. T. (2013). Effect of different drying techniques on flowability characteristics and chemical properties of natural carbohydrateprotein Gum from durian fruit seed. Chemistry Central Journal, 7(1), 1.

Mistry, V. V. (2002). Manufacture and application of high milk protein powder. Le Lait, 82(4), 515-522.

Morin, G., \& Briens, L. (2013). The effect of lubricants on powder flowability for pharmaceutical application. Aaps Pharmscitech, 14(3), 1158-1168.

Pathak, S. S., Pradhan, R. C., \& Mishra, S. (2019). Physical characterization and mass modeling of dried Terminalia chebula fruit. Journal of Food Process Engineering, 42(3), e12992.

Singh, I., \& Kumar, P. (2012). Preformulation studies for direct compression suitability of cefuroxime axetil and paracetamol: a graphical representation using SeDeM diagram. Acta Pol Pharm, 69(1), 87e93. 
Singh, R., Kaushik, R., \& Gosewade, S. (2018). Bananas as underutilized fruit having huge potential as raw materials for food and non-food processing industries: A brief review. The Pharma Innovation Journal, 7, 574-580.

Singh, R., Suvartan, S., \& Sukriti, M. (2017). Comparative Study of the Properties of Ripe Banana Flour, Unripe Banana Flour and Cooked Banana Flour Aiming Towards Effective Utilization of These Flours. International Journal of Current Microbiology and Applied Sciences, 6, 2003-2015.

Slettengren, K., Xanthakis, E., Ahrné, L., \& Windhab, E. J. (2016). Flow properties of spices measured with powder flow tester and ring shear tester-XS. International Journal of Food Properties, 19(7), 14751482.

Sonawane, A., Chauhan, O. P., Semwal, S. D., \& Semwal, A. D. (2021). Drying characteristics and lycopene degradation kinetics of tomato soup. Chemical Data Collections, 35, 100757.

Sonawane, A., Pathak, S. S., \& Pradhan, R. C. (2020a). Physical, thermal, and mechanical properties of bael fruit. Journal of Food Process Engineering, 43(6), e13393.

Sonawane, A., Pathak, S., \& Pradhan, R. C. (2020b). Effect of processing temperature on dynamic rheological properties and color degradation kinetics of bael fruit pulp. Journal of the Science of Food and Agriculture, 100(15), 5596-5602.

Yani, A., Arief, R. W., \& Mulyanti, N. (2013). Processing of banana flour using a local banana as raw materials in Lampung. International Journal on Advanced Science, Engineering and Information Technology, 3(4), 289-293.

\section{Acknowledgment}

No fund was offered from any organization or institute. 